retrobulbar) was in men $(43,5 \%)$ as wel as craniocerebral trauma $(22,5 \%)$, whereas in women the causative factors were primarily ischemic neuroopticopathy $(31.5 \%)$ and hypertonic disease $(21,4 \%)$.

Clinical data from patients' disease histories show that in addition to the characteristic ophthalmoscopic pattern of optic nerve atrophy, there was a significant reduction in visual acuity and narrowing of the total field of view with the presence of absolute scotoms in the central field of view.

The results of the treatment naturally raise the question of the effectiveness of medical care for patients. However, the analysis of the treatment of patients showed that the applied treatment tactics is consistent with medical aid protocols for patients with atrophy of the optic nerve.

Conclusions. Thus, a retrospective analysis of the patient's disease history of partial atrophy of the optic nerve allows us to draw the following conclusions: 1. Frequency PAON for the period of 2012-2016 amounted to 2,06 \%. 2. PAON affects population of working age (average age 50,0土2,5 years), that emphasizes the social significance of this problem. 3. Prevalently bilateral localization of the pathological process (in $86 \%$ of patients) increases the risk of disability due to this pathology. 4 . In women, partial AON is more common in vascular genesis (52,9\% of cases), and in men - inflammatory etiology ( $43,5 \%$ of cases).

Key words: optic nerve, optic nerve atrophy, distribution of optic nerve atrophy, etiology.

Стаття надійшла до редакції 29.03.2018 р.

А. С. Гудзь, Г. Є. Захаревич, О. В. Петренко, Г. Г. Луньова

Львівський національний медичний університет імені Данила Галицького МОЗ України

- м. Львів, Україна

\title{
ПРОГНОЗУВАННЯ РОЗВИТКУ ТА ПРОГРЕСУВАННЯ ДІАБЕТИЧНОЇ РЕТИНОПАТІЇ ПРИ ЦУКРОВОМУ ДІАБЕТІ 2-ГО ТИПУ
}

Метою дослідження було прогнозування розвитку та прогресування діабетичної ретинопатії (ДР) при цукровому діабеті 2-го типу (ЦД2Т) на підставі побудови і аналізу регресійних логістичних моделей з визначенням ймовірності розвитку ДР, а також швидкості ії прогресування. Залучено 302 особи: 1-а група ( $\mathrm{n}=76)$ - пацієнти з ДР без змін на очному дні; 2-a $(\mathrm{n}=64)$ - пацієнти 3 непроліферативною і 3-я $(\mathrm{n}=64)$ - 3 проліферативною ДР (ДПР). Контрольну групу склали 98 пацієнтів без цукрового діабету. При побудові логістичної регресії були враховані стать, вік, тривалість захворювання на діабет і результати генотипування поліморфізмів rs2010963 i rs699947 гена VEGFA. Аналіз ДНК-локусів здійснювали з використанням TaqMan Mutation Detection Assays Thermo Fisher Scientific (США) в автоматичному ампліфікаторі Real-Time PCR System 7500 (Applied Biosystems, США). Розраховані $\beta$-коефіцієнти математичної моделі розрахунку ймовірності розвитку ДР та ДПР для показників: “Тривалість захворювання на діабет”, “Стать” та “"rs2010963” вказували на наявність прямого, а для показників: “Вік” і “rs699947” - зворотного зв'язку з результуючою змінною. Модель розрахунку ймовірності розвитку ДР мала показник максимальної правдоподібності $(-2 * \log )=254,44$ при $\chi^{2}=157,2(\mathrm{p}<0,001)$ та високу прогностичну характеристику: область під кривою $(\mathrm{AUC})=0,90 \pm 0,02 ; 95 \% \mathrm{BI}=0,87-0,93 ; \mathrm{p}=1,24 \mathrm{E}-04$. Модель розрахунку ймовірності розвитку ДПР мала показник максимальної правдоподібності $(-2 * \log )=285,2$ при $\chi^{2}=168,04$ $(\mathrm{p}<0,001)$ та високу прогностичну характеристику: область під кривою (AUC) $=0,86 \pm 0,03$; $95 \% \mathrm{BI}=0,81-0,91 ; \mathrm{p}=2,15 \mathrm{E}-05$. Показана залежність прогресування ДР від генотипів rs2010963 i rs699947: представлені характеристики моделі демонстрували іï високу прогностичну здатність щодо залежного показника: $\mathrm{R}=0,714 ; \mathrm{R}^{2}=0,514 ; \mathrm{F}=93,9(\mathrm{p}<0,001)$.

Ключові слова: иукровий діабет 2-го типу, діабетична ретинопатія, ген VEGF, rs2010963, rs699947. 
Останнім часом в усьому світі спостерігається розвиток епідемії цукрового діабету 2-го типу (ЦД2Т), що виводить в пріоритетні задачі офтальмології ранню діагностику та прогнозування діабетичної ретинопатії (ДР) [1, 2]. Протягом перших десяти років захворювання частота розвитку ДР збільшується з $20 \%$ до майже $50 \%[3,4]$. Серед усіх ускладнень ЦД2Т ДР $\epsilon$ одним з найбільш несприятливих, оскільки призводить до сліпоти та інвалідизаціїі хворих $[1,2]$.

При виконанні досліджень, присвячених вивченню ролі генетичних факторів у патогенезі тих чи інших захворювань, завжди виникає необхідність розробки математичної моделі, яка, грунтуючись на результатах молекулярно-генетичних досліджень, може прогнозувати розвиток захворювання та/або його ускладнень [5]. Інтерес до таких розробок продиктований, насамперед, довічною стабільністю генного складу людини і результатами досліджень, які доводять вплив генетичного поліморфізму на перебіг захворювання. В якості методу розробки прогностичних рішень оптимальним $€$ використання регресійного аналізу [6].

Отже, метою даного дослідження було прогнозування розвитку та прогресування ДР при ЦД2Т на підставі побудови і аналізу регресійних логістичних моделей $з$ визначенням ймовірності розвитку ДР та ДПР, а також швидкості прогресування ДР.

Матеріали та методи. Дослідження виконано на кафедрі офтальмології Львівського національного медичного університету імені Данила Галицького. Загалом було залучено 302 особи, у тому числі 98 осіб контрольної групи (не мали ЦД2Т та ДР, а також інших офтальмологічних захворювань) та 204 особи - пацієнти з ЦД2Т. Встановлення діагнозу ДР проводилося за міжнародною клінічною класифікацією, прийнятою Американською академією офтальмології (2003). Пацієнтів було розподілено на 3 групи: 1-y групу склали 76 пацієнтів з ЦД 2-го типу, які за даними офтальмологічного дослідження не мали жодних проявів ретинопатії на очному дні; 2-y групу склали 64 пацієнти, в яких було діагностовано ДПР; 3-ю гру$n y-64$ пацієнти $з$ ДПР.

У даній роботі побудова і аналіз регресійних моделей проведено для вирішення таких діагностичних завдань:

- визначення ймовірності розвитку ДР $\left(\mathrm{P}_{\text {дР }}\right)$;

- визначення ймовірності розвитку ДПР $\left(\mathrm{P}_{\text {дпР }}\right)$ у хворих на ЦД2Т;

- визначення швидкості прогресування ДР у хворих на ЦД2Т.

Для вирішення перших двох завдань у якості моделі було використано багатофакторну логістичну регресію, побудовану методом максимальної правдоподібності; для третьої задачі був задіяний метод багатовимірних адаптивних регресійних (МАР) сплай- нів [5]. Усі розробки велися з урахуванням вагових характеристик предикторів. Вибір останніх був продиктований доцільністю практичного використання прогностичних моделей. У зв'язку з цим були відібрані показники, які могли бути легко отримані вже при первинному обстеженні хворих і мати стабільні характеристики або закономірну динаміку протягом життя. До таких показників було віднесено: стать, вік, тривалість захворювання на діабет і результати генотипування поліморфізмів (rs2010963 i rs699947 гена VEGFA), вплив яких, як було показано раніше $[7,8]$, є доведеним відносно розвитку захворювання. Аналіз поліморфних ДНК-локусів здійснювали 3 використанням уніфікованих тест-систем TaqMan Mutation Detection Assays Thermo Fisher Scientific (США) в автоматичному ампліфікаторі Real-Time PCR System 7500 (Applied Biosystems, CША). Поліморфізм rs2010963 гена VEGFA має хромосомну локалізацію Chr.6:43770613 on Build GRCh38 та локалізується у інтроні UTR5 гена. Цей поліморфізм являє собою просту нуклеотидну заміну (трансверзію) гуанінового нуклеотиду $(\mathrm{G})$ на цитідіновий $(\mathrm{C})$. Поліморфізм rs699947 гена VEGFA має хромосомну локалізацію Chr.6:43768652 on Build GRCh38 та локалізується у ділянці промотору гена. Цей поліморфізм являє собою просту нуклеотидну заміну (трансверзію) цитідінового нуклеотиду (С) на адениновий (А). Предковою алеллю $є$ алель А, мінорною - алель С. Забір крові для генетичних досліджень, як і для всіх інших, виконували за згодою пацієнта шляхом пункції ліктьової вени і забору 2,5 мл крові.

Результати та їх обговорення. В якості залежної змінної для прогнозування розвитку ДР був використаний діхотомічний категоріальний показник наявності або відсутності ДР у хворого. До аналізу були включені дані пацієнтів контрольної групи, 1-ї, 2-ї та 3-ї груп. Відсутність ДР презентовано значенням “N” для контрольної та 1-ї груn (всього 174 випадки), наявність ДР - "Ү" для 2-ї і 3-ї груn (всього 128 випадків). Відповідність предикторів і залежної змінної категоріальним, безперервним і індикаторним значенням при побудові рівняння логістичної регресії наведено в табл. 1.

Коефіцієнти регресійного рівняння та значущість їхньої відмінності від нульової гіпотези наведено в табл. 2.

Аналіз табличних даних підтверджує значимість зв'язку відібраних предикторів 3 результуючим показником регресійного рівняння - ймовірністю розвитку ДР, 3 високим ступенем значущості: "Вік" - p=3,96Е-06; "Стать" - p=2,11E-09; “Тривалість захворювання на діабет" - $\mathrm{p}<0,001$; "rs2010963" $\mathrm{p}=4,20 \mathrm{E}-06$; "rs699947" - $\mathrm{p}=4,50 \mathrm{E}-11$.

Розраховані $\beta$-коефіцієнти для показників: "Тривалість захворювання на діабет”, “Стать” та "rs2010963” 
Таблиия 1

Відповідність предикторів і залежної змінної категоріальним, безперервним і індикаторним значенням

\begin{tabular}{|c|c|c|c|c|}
\hline Показники & Категоріальні значення & Індикаторні значення & $\begin{array}{c}\text { Назва змінних } \\
\text { регресії }\end{array}$ & $\begin{array}{l}\text { Застосовується для } \\
\text { розрахунків: }\end{array}$ \\
\hline Вік (років) & - & - & $X_{1}$ & безперервне значення \\
\hline $\begin{array}{c}\text { Тривалість захворювання } \\
\text { на діабет (років) }\end{array}$ & - & - & $X_{2}$ & безперервне значення \\
\hline \multirow{2}{*}{ Стать } & Ч & 101 & \multirow{2}{*}{$\mathrm{X}_{3}$} & \multirow{2}{*}{ індикаторне значення } \\
\hline & Ж & 102 & & \\
\hline \multirow{3}{*}{ rs2010963 } & $\mathrm{G} / \mathrm{G}$ & 101 & \multirow{3}{*}{$\mathrm{X}_{4}$} & \multirow{3}{*}{ індикаторне значення } \\
\hline & $\mathrm{G} / \mathrm{C}$ & 102 & & \\
\hline & $\mathrm{C} / \mathrm{C}$ & 103 & & \\
\hline \multirow{3}{*}{ rs699947 } & $\mathrm{C} / \mathrm{C}$ & 101 & \multirow{3}{*}{$\mathrm{X}_{5}$} & \multirow{3}{*}{ індикаторне значення } \\
\hline & $\mathrm{C} / \mathrm{A}$ & 102 & & \\
\hline & $\mathrm{A} / \mathrm{A}$ & 103 & & \\
\hline \multirow{2}{*}{$\begin{array}{c}\text { Ймовірність наявності } \\
\text { ДР }\end{array}$} & $\mathrm{N}$ & 0 & \multirow{2}{*}{ Р(ДР) } & \multirow{2}{*}{ індикаторне значення } \\
\hline & $\mathrm{Y}$ & 1 & & \\
\hline
\end{tabular}

Коефіцієнти регресійного рівняння та їхня статистична значущість

Таблиияя 2

\begin{tabular}{|c|c|c|c|c|c|}
\hline Предиктори & $\beta$ & $\pm S E$ & Wald & $95 \%$ BI & $p$ \\
\hline Вік & $-0,008$ & 0,002 & 21,285 & $-(0,012-0,005)$ & $3,96 \mathrm{E}-06$ \\
\hline Тривалість захворювання на діабет & 0,348 & 0,004 & 7351,156 & $0,340-0,356$ & $<0,001$ \\
\hline Стать & 0,205 & 0,034 & 35,873 & $0,138-0,272$ & $2,11 \mathrm{E}-09$ \\
\hline rs2010963 & 0,130 & 0,028 & 21,173 & $0,075-0,185$ & $4,20 \mathrm{E}-06$ \\
\hline rs699947 & $-0,272$ & 0,041 & 43,382 & $-(0,354-0,191)$ & $4,50 \mathrm{E}-11$ \\
\hline Вільний показник & $-7,877$ & 0,381 & 11,139 & $-(22,344-6,590)$ & $2,86 \mathrm{E}-03$ \\
\hline
\end{tabular}

Примітки:

$\beta$ - коефіцієнт регресії;

$\pm \mathrm{SE}$ - стандартна похибка $\beta$-коефіцієнтів;

Wald - показник Wald-статистики;

$95 \%$ ВI - $95 \%$ вірогідний інтервал;

p - значущість відмінності від нульової гіпотези (прийнята, якщо $\mathrm{p}<0,05$ )

вказували на наявність прямого, а для показників: “Вік” і “rs699947” - зворотного зв'язку з результуючою змінною. Тобто ймовірність розвитку ДР була вищою при тривалому перебігу ЦД2Т, залежала від статі (була вищою у жінок) та наявності генотипів G/C i $\mathrm{C} / \mathrm{C}$ rs2010963. Відповідно ймовірність розвитку ДР була нижчою у осіб молодшого віку та за наявності генотипу C/A та A/A rs699947.

Модель розрахунку ймовірності розвитку ДР, побудована нами, мала показник максимальної правдоподібності $(-2 * \log )=254,44$ при $\chi^{2}=157,2 \quad(\mathrm{p}<0,001)$. Також і характеристики ROC-аналізу свідчили про високі прогностичні характеристики регресії: область під кривою $(\mathrm{AUC})=0,90 \pm 0,02 ; 95 \%$ \% $=0,87-0,93$; $\mathrm{p}=1,24 \mathrm{E}-04$.

Таким чином, для розрахунку ймовірності розвитку ДР можна користуватися наступною формулою:

$\mathrm{P}_{\text {дР }}=1 /\left(1+e^{\left(7,877+0,008 * \mathrm{X}_{1}-0,448 * \mathrm{X}_{2}-0,205 * \mathrm{X}_{2}-0,130 * \mathrm{X}_{4}+0,272 * \mathrm{X}_{5}\right)}\right)(1)$,

де $\mathrm{P}_{\text {дР }}$ - ймовірність розвитку ДР; $\mathrm{X}_{1}$ - вік пацієнта (років); $\mathrm{X}_{2}$ - тривалість захворювання на діабет (ро- ків); $\mathrm{X}_{3}$ - стать (індикаторні значення: для чоловіків 101, для жінок - 102); $X_{4}$ - генотип rs2010963 (індикаторні значення: для $\mathrm{G} / \mathrm{G}-101$, для $\mathrm{G} / \mathrm{C}-102$, для C/C - 103); $\mathrm{X}_{5}$ - генотип rs699947 (індикаторні значення: для $\mathrm{C} / \mathrm{C}-101$, для $\mathrm{C} / \mathrm{A}-102$, для $\mathrm{A} / \mathrm{A}-103$ ).

Точка рівноваги логістичної регресії відповідала значенню $\mathrm{P}_{\text {др }}=0,402$. Класифікаційні характеристики моделі в точці рівноваги наведено в табл. 3 .

Таким чином, проведений аналіз показав, що в точці відсікання $\mathrm{P}_{\text {дР }}=0,402$ може бути досягнуте безпомилкове прогнозування розвитку ретинопатії 79,8 \% при відповідності розрахункових результатів фактичним: у класі позитивних результатів - у 79,7 \% i негативних - у 79,9 \% випадків $(\mathrm{OR}=0,99 ; 95 \%$ ВI 0,56-1,74).

Приклади практичного використання розробленої моделі прогнозування розвитку ДР:

1. Пацієнт Ч., 71 рік, тривалість захворювання на ЦД2Т 7 років, віднесений до 2-ї групи з діагнозом ДНПР. Результати генотипування VEGFA: rs2010963 
Класифікаційні характеристики регресійної моделі прогнозування ймовірності розвитку ДР

\begin{tabular}{|c|c|c|c|c|c|c|}
\hline \multirow{2}{*}{ Категорії змінної ДР } & \multicolumn{2}{|c|}{$\begin{array}{c}\text { Прогнозовані класи } \\
\text { змінної ДР, } n\end{array}$} & \multirow{2}{*}{$\begin{array}{c}\text { Правильний прогноз } \\
\text { за класами, \% }\end{array}$} & \multirow{2}{*}{$\begin{array}{c}\text { Правильний прогноз } \\
\text { за моделлю, \% }\end{array}$} & \multirow[t]{2}{*}{$O R$} & \multirow{2}{*}{$95 \% B I$} \\
\hline & "Y" & "N" & & & & \\
\hline "Y" & 102 & 25 & 79,7 & \multirow{2}{*}{79,8} & \multirow{2}{*}{0,99} & \multirow{2}{*}{$0,56-1,74$} \\
\hline$" \mathrm{~N} "$ & 35 & 139 & 79,9 & & & \\
\hline
\end{tabular}

Примітки:

“Y” i “N” - категоріальні значення змінної (характеризує наявність або відсутність ДР, відповідно);

$\mathrm{n}$ - число спостережень;

OR - відношення шансів;

$95 \%$ ВI - $95 \%$ вірогідний інтервал

Таблицяя 4

Коефіцієнти регресійного рівняння та їхня статистична значущість

\begin{tabular}{|c|c|c|c|c|c|}
\hline Предиктори & $\beta$ & $\pm S E$ & Wald & $95 \%$ BI & $p$ \\
\hline Вік & $-0,086$ & 0,002 & 1405,889 & $-(0,009-0,081)$ & $<0,001$ \\
\hline Тривалість захворювання на діабет & 0,181 & 0,004 & 2602,509 & $0,174-0,188$ & $<0,001$ \\
\hline Стать & 0,569 & 0,041 & 190,988 & $0,488-0,649$ & $<0,001$ \\
\hline rs2010963 & 0,706 & 0,032 & 494,720 & $0,644-0,768$ & $<0,001$ \\
\hline rs699947 & $-0,633$ & 0,044 & 206,275 & $-(0,719-0,547)$ & $<0,001$ \\
\hline Вільний показник & $-62,097$ & 8,402 & 54,624 & $-(78,565-45,63)$ & $1,46 \mathrm{E}-13$ \\
\hline
\end{tabular}

Примітки:

$\beta$ - коефіцієнт регресії;

$\pm \mathrm{SE}$ - стандартна похибка $\beta$-коефіцієнтів;

Wald - показник Wald-статистики;

95 \% ВI - 95 \%-й вірогідний інтервал;

p - значущість відмінності від нульової гіпотези (прийнята, якщо $\mathrm{p}<0,05$ )

- генотип G/A; rs699947 - генотип C/C. Розрахункова ймовірність розвитку ДР: $\mathrm{P}_{\text {дР }}=0,765$ - перевищує точку відсічі $(0,402)$, що відповідало діагнозу ДПР.

2. Пацієнтка K., 42 роки, тривалість захворювання на ЦД2Т 2 роки, віднесена до 1-ї групи. Результати генотипування VEGFA: rs2010963 - G/G; rs699947 - C/A. Розрахункова ймовірність розвитку ДР: $\mathrm{P}_{\text {дР }}=0,265$ - нижче точки відсікання $(0,402)$, що відповідало діагнозу ДР без ретинопатії.

Для вирішення наступного завдання - визначення ймовірності розвитку ДПР у хворих на ЦД2Т - в якості залежної змінної було використано бінарну змінну, яка описує наявність або відсутність ДПР. В аналіз були включені пацієнти з ЦД2Т 1-ї, 2-ї і 3-ї груn. При відсутності у хворих ознак ДПР (1-a і 2-a групи, всього 140 спостережень) змінній привласнювали категоріальне значення "N", а при наявності ДПР (3-я група, всього 64 спостереження) - "Y". Відповідність предикторів і залежної змінної категоріальним, безперервним і індикаторним значенням при побудові рівняння логістичної регресії були аналогічні наведеним у табл. 1.

Коефіцієнти регресійного рівняння та статистична значущість їхньої відмінності від нульової гіпотези наведено в табл. 4.

Розраховані $\beta$-коефіцієнти для показників: "Тривалість захворювання на діабет”, “Стать”, “rs2010963” вказували на наявність прямого, а для показників: “Вік" і “rs699947" - зворотного зв'язку з результуючою змінною і статистично значуще відрізнялися від нульової гіпотези: $\mathrm{p}<0,001$ у всіх випадках. Тобто ймовірність розвитку ДПР була вищою при тривалому перебігу ЦД2Т, залежала від статі (була вищою у жінок) та за наявності генотипів G/C та C/C rs2010963. Відповідно ймовірність розвитку ДПР була нижчою у осіб молодшого віку та за наявності генотипу С/А та A/A rs699947. Такі результати були аналогічні отриманим при розрахунку ймовірності прогнозу ДР, за вищенаведеною формулою.

Побудована модель розрахунку ймовірності розвитку ДПР мала показник максимальної правдоподібності $(-2 * \log )=285,2$ при $\chi^{2}=168,04 \quad(\mathrm{p}<0,001)$. Характеристики ROC-аналізу свідчили про високі прогностичні характеристики регресії: область під кривою (AUC) $=0,86 \pm 0,03 ; 95 \% \mathrm{BI}=0,81-0,91$; $\mathrm{p}=2,15 \mathrm{E}-05$.

Таким чином для розрахунку ймовірності розвитку ДПР можна користуватися наступною формулою:

$\mathrm{P}_{\text {дाР }}=1 /\left(1+e^{\left(62,097+0,086 * \mathrm{X}_{1}-0,181 * \mathrm{X}_{2}-0,569 * \mathrm{X}_{3}-0,706 * \mathrm{X}_{4}+0,633 * \mathrm{X}_{5}\right)}\right)(2)$,

де $\mathrm{P}_{\text {дпР }}$ - ймовірність розвитку ДПР; $\mathrm{X}_{1}$ - вік пацієнта (років); $\mathrm{X}_{2}$ - тривалість захворювання на діабет (років); $\mathrm{X}_{3}$ - стать (індикаторні значення: для чоловіків - 101, для жінок - 102); $\mathrm{X}_{4}$ - генотип rs2010963 (ін- 
Класифікаційні характеристики регресійної моделі прогнозування ймовірності розвитку ДПР

Таблиия 5

\begin{tabular}{|c|c|c|c|c|c|c|}
\hline \multirow[t]{2}{*}{ Категорї змінної ДР } & \multicolumn{2}{|c|}{$\begin{array}{c}\text { Прогнозовані класи } \\
\text { змінної ДПР, } n\end{array}$} & \multirow{2}{*}{$\begin{array}{c}\text { Правильний прогноз } \\
\text { за класами, \% }\end{array}$} & \multirow{2}{*}{$\begin{array}{c}\text { Правильний прогноз } \\
\text { за моделлю, \% }\end{array}$} & \multirow[t]{2}{*}{$O R$} & \multirow[t]{2}{*}{$95 \% B I$} \\
\hline & "Y" & "N" & & & & \\
\hline "Y" & 50 & 14 & 78,1 & \multirow{2}{*}{78,9} & \multirow{2}{*}{0,93} & \multirow{2}{*}{$0,45-1,92$} \\
\hline "N" & 29 & 111 & 79,3 & & & \\
\hline
\end{tabular}

Примітки:

"Y” i "N" - категоріальні значення змінної (характеризує наявність або відсутність ДР, відповідно);

$\mathrm{n}$ - число спостережень;

$\mathrm{OR}$ - відношення шансів;

95 \% ВI - 95 \%-й вірогідний інтервал

Таблиия 6

Відповідність предикторів і залежної змінної категоріальним, безперервним і індикаторним значенням

\begin{tabular}{|c|c|c|c|c|}
\hline Показники & Категоріальне значення & Індикаторні значення & $\begin{array}{c}\text { Назва змінних } \\
\text { регресї̈ }\end{array}$ & $\begin{array}{c}\text { Застосовується для } \\
\text { розрахунків }\end{array}$ \\
\hline \multirow{3}{*}{ rs2010963 } & $\mathrm{G} / \mathrm{G}$ & 101 & \multirow{3}{*}{$\mathrm{X}_{1}$} & \multirow{3}{*}{ індикаторне значення } \\
\hline & $\mathrm{G} / \mathrm{C}$ & 102 & & \\
\hline & $\mathrm{C} / \mathrm{C}$ & 103 & & \\
\hline \multirow{3}{*}{ rs699947 } & $\mathrm{C} / \mathrm{C}$ & 101 & \multirow{3}{*}{$X_{2}$} & \multirow{3}{*}{ індикаторне значення } \\
\hline & $\mathrm{C} / \mathrm{A}$ & 102 & & \\
\hline & $\mathrm{A} / \mathrm{A}$ & 103 & & \\
\hline $\mathrm{v}(Д Р)$ & - & - & v(ДР) & безперервне значення \\
\hline
\end{tabular}

дикаторні значення: для $\mathrm{G} / \mathrm{G}$ - 101, для $\mathrm{G} / \mathrm{C}-102$, для $\mathrm{C} / \mathrm{C}$ - 103); $\mathrm{X}_{5}$ - генотип rs699947 (індикаторні значення: для $\mathrm{C} / \mathrm{C}-101$, для $\mathrm{C} / \mathrm{A}-102$, для $\mathrm{A} / \mathrm{A}-103)$.

Точка рівноваги логістичної регресії відповідала значенню $\mathrm{P}_{\text {дпР }}=0,315$. Класифікаційні характеристики моделі в точці рівноваги наведені в табл. 5, 3 якої витікає, що в точці відсікання $\mathrm{P}_{\text {дпр }}=0,315$ було досягнуте безпомилкове прогнозування розвитку ДПР - 78,9 \% при відповідності розрахункових результатів фактичним: у класі позитивних результатів - 78,1 \% і негативних - в 79,3 \% випадків (OR=0,93; 95 \% BI 0,45-1,92).

Приклади практичного використання розробленої моделі прогнозування розвитку ДПР:

1. Паиієнтка Г., 59 років, тривалість захворювання на ЦД2Т 9 років, віднесена до 3-ї групи з діагнозом ДПР. Результати генотипування VEGFA: rs2010963 - A/A; rs699947 - C/A. Розрахункова ймовірність розвитку ДПР: $\mathrm{P}_{\text {дпР }}=0,657$ - перевищує точку відсікання (0,315). Фактично при обстеженні у хворої виявлено ДПР.

2. Пацієнт B., 72 роки, тривалість захворювання на ЦД2Т 10 років, віднесений до 1-ї групи. Результати генотипування VEGFA: rs2010963 - G/G; rs699947 - C/C. Розрахункова ймовірність розвитку ДПР: $\mathrm{P}_{\text {дпР }}=0,119$ - нижче точки відсікання $(0,315)$. При обстеженні ознак ДР не виявлено.

Третім і останнім завданням цього дослідження було визначення швидкості прогресування ДР у хворих на ЦД2Т, що, на нашу думку, було нерозривно пов'язане 3 ключовими питаннями всіх досліджень, заснованих на вивченні впливу молекулярно-генетичних маркерів на хвороби, а саме - яким чином гено- тип впливає на прогресування захворювання i його ускладнень і в якому віці слід очікувати ту або іншу стадію хвороби.

У зв'язку з цим в якості результуючого показника для проведення регресійного аналізу нами був запропонований показник швидкості прогресування ДР, який розраховували за формулою:

$$
v(Д Р)=s t(Д Р) / a g e
$$

де $\mathrm{v}(Д Р)$ - швидкість прогресування ДР; st(ДР) стадія ДР на момент первинного огляду; age - вік пацієнта в роках на момент первинного огляду.

В якості незалежних показників були використані індикаторні значення генотипів rs2010963 і rs699947 гена VEGFa. До аналізу були включені пацієнти 1-ї (76 спостережень), 2-ї і 3-ї груn (по 64 спостереження).

Відповідність предикторів і залежної змінної категоріальним, безперервним і індикаторним значенням при побудові рівняння регресії наведено в табл. 6 .

Беручи до уваги характер розподілу даних для побудови регресійної моделі, був задіяний метод багатовимірних адаптивних регресійних (МАР) сплайнів [5]. Всі розробки велися з урахуванням вагових характеристик предикторів. Отримані коефіцієнти регресійного рівняння та статистична значущість їхньої відмінності від нульової гіпотези подані в табл. 7.

У табл. 8 подані результати оцінки регресійної моделі.

Представлені характеристики моделі демонстрували іiі високу прогностичну здатність щодо залежного показника: $\mathrm{R}=0,714 ; \mathrm{R}^{2}=0,514 ; \mathrm{F}=93,9$ ( $\left.\mathrm{p}<0,001\right)$. У 
Коефіціснти регресійного рівняння залежності швидкості

прогресування ДР від генотипів rs2010963 i rs699947 гена VEGFA

\begin{tabular}{|c|c|c|c|c|c|}
\hline Предиктори & $\beta$ & $\pm S E$ & $95 \%$ BI & $t$ & $p$ \\
\hline rs2010963 & 0,007 & 0,001 & $0,006-0,007$ & 21,966 & $<0,001$ \\
\hline rs699947 & $-0,010$ & 0,001 & $-(0,011-0,009)$ & $-22,314$ & $<0,001$ \\
\hline Вільний показник & 0,061 & 0,003 & $0,033-0,035$ & 66,991 & $<0,001$ \\
\hline
\end{tabular}

Примітки:

$\beta$ - коефіцієнт регресії;

$\pm \mathrm{SE}$ - стандартна похибка $\beta$-коефіцієнтів;

95 \% ВI - 95 \% вірогідний інтервал;

$\mathrm{t}$ - коефіцієнт Стьюдента;

p - статистична значущість відмінності від нульової гіпотези (прийнята при $p<0,05$ )

Таблиия 8

Характеристики регресійної моделі залежності швидкості прогресування ДР від генотипів rs2010963 i rs699947 гена VEGFA

\begin{tabular}{|c|c|c|c|c|c|c|}
\hline$v(Д Р)$ & $M$ & $\pm m$ & $R$ & $R^{2}$ & $F$ & $p$ \\
\hline Фактичні значення & 0,029 & 0,003 & \multirow{3}{*}{0,714} & \multirow{3}{*}{0,514} & \multirow{3}{*}{93,86} & \multirow{3}{*}{$<0,001$} \\
\hline Прогнозовані значення & 0,029 & 0,007 & & & & \\
\hline $\begin{array}{c}\text { Різниця між фактичними і прогнозованими } \\
\text { величинами }\end{array}$ & $-0,000$ & 0,031 & & & & \\
\hline
\end{tabular}

\section{Примітки:}

v(ДР) - швидкість прогресування ДР;

$\mathrm{M} \pm \mathrm{m}$ - середня і стандартна похибка середньої;

$\mathrm{R}$ - коефіцієнт кореляції регресійної моделі;

$\mathrm{R}^{2}$ - коефіцієнт детермінації регресійної моделі;

F - коефіцієнт Фішера для дисперсійної характеристики моделі і розрахунку значущості відмінності з нульовою гіпотезою;

p - значущість відмінностей (прийнята при р <0,05)

зв'язку з цим для розрахунку швидкості прогресування ДР в залежності від генотипів rs2010963 і rs699947 гена VEGFA доцільно використовувати таку формулу: $v($ ДР $)=0,061-0,010^{*} \max \left(0 ; \mathrm{X}_{2}-101\right)+0,007 * \max \left(0 ; \mathrm{X}_{1}-101\right)(4)$,

де $\mathrm{v}(Д Р)$ - швидкість прогресування ДР; $\max -$ функція вибору максимального аргументу 3 двох можливих; $\mathrm{X}_{1}$ - генотип rs2010963 (індикаторні значення: для $\mathrm{G} / \mathrm{G}-101$, для $\mathrm{G} / \mathrm{C}-102$, для $\mathrm{C} / \mathrm{C}-103)$; $\mathrm{X}_{2}$ - генотип rs699947 (індикаторні значення: для C/C - 101, для C/A - 102, для A/A - 103).

Для практичного використання моделі прогнозування швидкості прогресування ДР в середовищі табличного процесора Excel (Microsoft Corp., США) реалізовано обчислювальну систему, яка працює на підставі отриманих рівнянь. На рисунку приведений iї інтерфейс.

Для роботи в програмі у відповідні осередки табличного процесора необхідно ввести значення показників для конкретного пацієнта. Система автоматично розраховує швидкість прогресування ДР, стадію ДР згідно віку і вік, при якому слід очікувати певну стадію ДР.

Приклади практичного використання розробленої моделі прогнозування:
1. Пацієнт Д., 55 років. Результати генотипування VEGFA: rs2010963 - G/G; rs699947 - C/А. Швидкість прогресування ДР: $\mathrm{v}(Д Р)=0,051$ стадій/рік. Розрахункова стадія ДР при актуальному віці пацієнта - 3, що відповідає діагнозу ДПР. Розрахунковий вік, при якому слід очікувати перехід 3-ї стадії в 4-у, - 79 років. Фактично у хворого виявлено ДПР (3-я стадія).

2. Пацієнтка 3., 51 рік. Результати генотипування VEGFA: rs2010963 - G/C; rs699947 - A/А. Швидкість прогресування ДР: v(ДР)=0,047 стадій/рік. Розрахункова стадія ДР при актуальному віці пацієнтки - 2, що відповідає ДПР. Розрахунковий вік, при якому слід очікувати перехід ДР з 2-ї стадії в 3-ю, - 64 роки, у 4-у - 85 років. Фактично на момент обстеження у хворої виявлено ДПР (2-га стадія).

3. Пацієнтка М., 50 років. Результати генотипування VEGFA: rs2010963 - C/C; rs699947 - C/C. Швидкість прогресування ДР: v(ДР $=0,074$ стадій/ рік. Розрахункова стадія ДР при актуальному віці пацієнтки - 4, що відповідає ДПР. Розрахунковий вік, при якому слід очікувати перехід ДР з 4-ї стадії в 5-у, - 68 років. Фактично на момент обстеження у хворої виявлено ДПР (4-а стадія). 


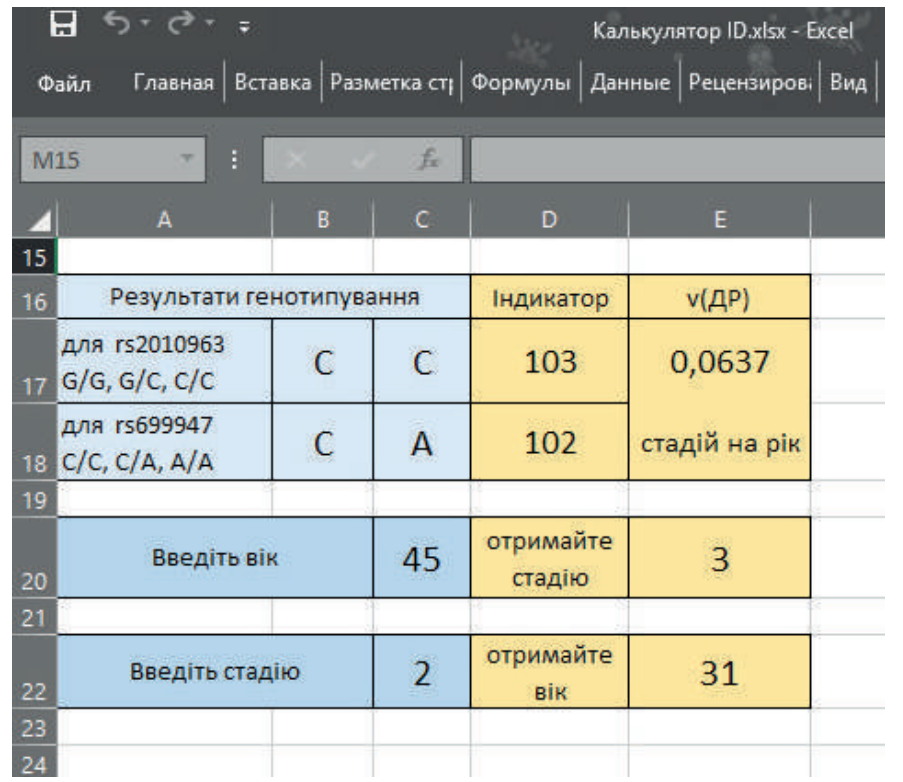

Рис. Інтерфейс обчислювальної системи для розрахунків швидкості прогресування ДР, стадії хвороби або віку хворих в залежності від генотипів rs2010963 i rs699947 гена VEGFA (файл Калькулятор ID.xlsx)

\section{Висновки}

1. Розраховані $\beta$-коефіцієнти математичної моделі розрахунку ймовірності розвитку ДР для показників: “Тривалість захворювання на діабет”, “Стать” та "rs2010963" вказували на наявність прямого, а для показників: “Вік” і “rs699947” - зворотного зв’язку $з$ результуючою змінною. Модель мала показник максимальної правдоподібності $(-2 * \log )=254,44$ при $\chi^{2}=157,2(\mathrm{p}<0,001)$ та високу прогностичну характеристику: область під кривою $(\mathrm{AUC})=0,90 \pm 0,02 ; 95 \%$ $\mathrm{BI}=0,87-0,93 ; \mathrm{p}=1,24 \mathrm{E}-04$. Для значення $\mathrm{P}_{\text {дР }}=0,402$ безпомилкове прогнозування розвитку ДР складало 79,8 \% при відповідності розрахункових результатів фактичним: у класі позитивних результатів - в 79,7 \% і негативних - в 79,9 \% випадків $(\mathrm{OR}=0,99 ; 95 \%$ ВI 0,56-1,74).

2. Розраховані $\beta$-коефіцієнти математичної моделі розрахунку ймовірності розвитку ДПР для показників "Тривалість захворювання на діабет", “Стать”, "rs2010963" вказували на наявність прямого, а для показників: "Вiк” i “rs699947” - зворотного зв’язку з результуючою змінною і статистично значуще відрізнялися від нульової гіпотези: $\mathrm{p}<0,001$ у всіх випадках. Побудована модель розрахунку ймовірності розвитку ДПР мала показник максимальної правдоподібності
$(-2 * \log )=285,2$ при $\chi^{2}=168,04(\mathrm{p}<0,001)$ та високу прогностичну характеристику: область під кривою $(\mathrm{AUC})=0,86 \pm 0,03 ; 95 \% \mathrm{BI}=0,81-0,91 ; \mathrm{p}=2,15 \mathrm{E}-05$. Для значення $\mathrm{P}_{\text {дпР }}=0,315$ було досягнуте безпомилкове прогнозування розвитку ДПР - 78,9 \% при відповідності розрахункових результатів фактичним: у класі позитивних результатів - 78,1 \% і негативних - у 79,3 \% випадків (OR=0,93; $95 \%$ BI 0,45-1,92).

3. Показана залежність прогресування ДР від генотипів rs2010963 i rs699947: представлені характеристики моделі демонстрували іiі високу прогностичну здатність щодо залежного показника: $\mathrm{R}=0,714$; $\mathrm{R}^{2}=0,514 ; \mathrm{F}=93,9(\mathrm{p}<0,001)$.

\section{Література}

1. Sayin N. Ocular complications of diabetes mellitus / N. Sayin, N. Kara, G. Pekel // World J Diabetes. 2015. - Vol. 6, № 1. - P. 92-108.

2. Scanlon P. H. Epidemiological issues in diabetic retinopathy / P. H. Scanlon, S. J. Aldington, I. M. Stratton // Middle East Afr. J. Ophthalmol. - 2013. - Vol. 20, № 4. - Р. 293-300.

3. Власенко М. В. Цукровий діабет: діагностика і моніторинг / М. В. Власенко // Ліки України. - 2013. - № 9-10. - С. 17-18.

4. Паньків B. I. Симпозіум № 162 “Цукровий діабет: діагностичні критерії, етіологія і патогенез” / В. I. Паньків // Міжнародний ендокринологічний журнал. - 2013. - № 8. - С. 53-64.

5. Боровиков В. П. STATISTICA. Искусство анализа данных на компьютере: для профессионалов / В. П. Боровиков. - [2-е издание]. - СПб.: Питер, 2003. -688 c.

6. Мун С. А. Регрессионный анализ в медико-биологических исследованиях / С. А. Мун, А. Н. Глушков, Т. А. Штернис. - Кемерово : КемГМА, 2012 . 119 c.

7. Риков С. О. Поліморфні варіанти гена VEGF rs 6921438 та rs 2010963 при діабетичній ретинопатії / С. О. Риков, А. С. Гудзь, Г. С. Захаревич // Архів офтальмології України. - 2015. - Т. 3, № 1. - С. 36-40.

8. Гудзь А. С. Розподіл генотипів та асоціація поліморфізмів гена VEGF (RS2010963 та RS69994) з діабетичною ретинопатією і цукровим діабетом 2-го типу / А. С. Гудзь, Г. Є. Захаревич // Архів офтальмології України. - 2017. - Т. 5, № 1 (7). - С. 16-20.

\section{ПРОГНОЗИРОВАНИЕ РАЗВИТИЯ И ПРОГРЕССИРОВАНИЯ ДИАБЕТИЧЕСКОЙ РЕТИНОПАТИИ ПРИ САХАРНОМ ДИАБЕТЕ 2-ГО ТИПА}

\section{А. С. Гудзь, Г. Е. Захаревич, О. В. Петренко, А. Г. Лунёва}

Целью исследования было прогнозирование развития и прогрессирования диабетической ретинопатии (ДР) при сахарном диабете 2-го типа (ЦД2Т) на основании построения и анализа регрессионных логистических моделей с определением вероятности развития ДР, а также скорости ее прогрессирования. В исследовании 
приняли участие 302 пациента: 1-я группа (n=76) - пациенты с ДР без изменений на глазном дне; 2-я (n=64) пациенты с непролиферативной и 3-я (n=64) - с пролиферативной ДР (ДПР). Контрольную группу составили 98 пациентов без сахарного диабета. При построении логистической регрессии были учтены пол, возраст, длительность протекания диабета и результаты генотипирования полиморфизмов rs2010963 и rs699947 гена VEGF. Анализ ДНК-локусов осуществляли с использованием TaqMan Mutation Detection Assays Thermo Fisher Scientific (США) в автоматическом амплификаторе Real-Time PCR System 7500 (Applied Biosystems, CША). Рассчитанные $\beta$-коэффициенты математической модели расчета вероятности развития ДР и ДПР для показателей: “Длительность протекания диабета", “Пол” и "rs2010963” указывали на наличие прямой, а для показателей: “Возраст” и "rs699947” - обратной связи с результирующей переменной. Модель расчета вероятности развития ДР имела показатель максимального правдоподобия $(-2 * \log )=254,4$ при $\chi^{2}=157,2(\mathrm{p}<0,001)$ и высокую прогностическую характеристику: область под кривой (AUC) $=0,90 \pm 0,02 ; 95 \%$ ДИ=0,87-0,93; $\mathrm{p}=1,24 \mathrm{E}-04$. Модель расчета вероятности развития ДПР имела показатель максимального правдоподобия $(-2 * \log )=285,2$ при $\chi^{2}=168,04$ ( $\left.<0,001\right)$ и высокую прогностическую характеристику: область под кривой (AUC) $=0,86 \pm 0,03 ; 95 \%$ ДИ=0,81-0,91; $\mathrm{p}=2,15 \mathrm{E}-05$. Показана зависимость прогрессирования ДР от генотипов rs2010963 и rs699947: представленные характеристики модели демонстрировали ее высокую прогностическую способность по зависимому показателю: $\mathrm{R}=0,714 ; \mathrm{R}^{2}=0,514 ; \mathrm{F}=93,9$ ( $\mathrm{p}<0,001$ ).

Ключевые слова: сахарный диабет 2-го типа, диабетическая ретинопатия, ген VEGF, rs2010963, rs699947.

\title{
DIABETIC RETINOPATHY DEVELOPMENT AND PROGRESSING PREDICTION IN DIABETES MELLITUS TYPE 2
}

\author{
A. S. Hudz, G. E. Zakharevich, O. V. Petrenko, H. H. Lunova
}

Lviv National Medical University named after Danylo Halytskyi of the Ministry of Public Health of Ukraine Lviv, Ukraine

Summary. The aim of the study was to predict the development and progression of diabetic retinopathy (DR) in type 2 diabetes mellitus (CD2T), based on the construction and analysis of regression logistic models with the definition of the probability of development of DR and to calculate the rate of its progression. 302 patients were included in the study: the 1st group ( $\mathrm{n}=76)$ patients with $\mathrm{DR}$ without any evident changes on the fundus; $2 \mathrm{nd}(\mathrm{n}=64)$ - patients with nonproliferative DR and 3-rd ( $\mathrm{n}=64)$ - with proliferative DR (DPR). The control group included 98 patients without diabetes mellitus. To construct the logistic regression, sex, age, duration of diabetes parameters and the results of genotyping polymorphisms rs2010963 and rs699947 of the VEGF gene were selected. DNA loci analysis was performed using TaqMan Mutation Detection Assays Thermo Fisher Scientific (USA) in the Real-Time PCR System 7500 automatic regulator (Applied Biosystems, USA). The calculated $\beta$-coefficients of the mathematical model for calculating the probability of development of DR and DPR for indicators: "Duration of diabetes", "Sex" and "rs2010963" indicated the presence of a direct link, and for the indicators: "Age" and "rs699947" - feedback link from the resulting variable. The model for calculating the likelihood of DR development had a maximum likelihood index $(-2 * \log )=254.4$ for $\chi^{2}=157.2(\mathrm{p}<0.001)$ and a high predictive response: the region under the curve $(\mathrm{AUC})=0.90 \pm 0.02$; $95 \% \mathrm{CI}=0.87-0.93 ; \mathrm{p}=1.24 \mathrm{E}-04$. The model for calculating the likelihood of DPR development had a maximum likelihood index $(-2 * \log )=285.2$ for $\chi^{2}=168.04(\mathrm{p}<0.001)$ and a high predictive response: the region under the curve $(\mathrm{AUC})=0.86 \pm 0.03 ; 95 \% \mathrm{CI}=0.81-0.91 ; \mathrm{p}=2.15 \mathrm{E}-05$. The dependence of the progression of DR from the genotypes rs2010963 and rs699947 is shown: the presented characteristics of the model demonstrated its high prognostic ability according to the dependent index: $\mathrm{R}=0.714 ; \mathrm{R}^{2}=0.514 ; \mathrm{F}=93.9(\mathrm{p}<0.001)$.

Key words: diabetes mellitus type 2, diabetic retinopathy, VEGF gene, rs2010963, rs699947.

Стаття надійшла до редакції 29.01.2018 p. 